DOI: $10.19195 / 0137-1150.167 .34$

\author{
ANNA BOGINSKAYA
}

Uniwersytet Wrocławski, Polska

\title{
Мотив смерти в романтическом любовном дискурсе современной польской и русской прозы (на материале произведений Пастух и пастушка Виктора Астафьева, Хроника любовных происшествий Тадеуша Конвицкого)
}

Понятие романтической любви, формировавшееся в течение столетий в европейской истории и культуре, имеет мало общего с его обиходным пониманием. Модель романтической любви начинает складываться в Средневековье, уже в это время в ней обнаруживается симбиоз любви и смерти, эроса и танатоса, что стало одной из наиболее характерных ее черт ${ }^{1}$.

В свою очередь, системы символов, вошедшие в структуру представления о романтической любви в Средние века, щедро заимствовались из античной культуры и христианства. На становление этих представлений повлияли исторические и культурные изменения тех лет. Нидерландский философ, историк и исследователь культуры Йохан Хейзинга выделяет три основных любовных стиля, сформировавшихся в Средневековье: куртуазный, пасторальный и эротическо-чувственный ${ }^{2}$.

Нас интересует прежде всего куртуазный стиль, порожденный идеалами рыцарства и ставший основой представлений об идеальной любви. Он был запечатлен в напевах провансальских трубадуров и обычаях, связанных с турнирами. Этот стиль проявлялся в „служении замужней даме, вознесенном трубадурами в заоблачные выси в качестве недосягаемого

\footnotetext{
${ }^{1}$ L. Pearce, Romance Writing, Cambridge 2007, c. 85.

2 Й. Хейзинга, Осень Средневековья, пер. Д. Сильвестров, Москва 1995, с. 114-120.
} 
предмета вожделенного почитания"3. Основным пунктом этой любовной доктрины было соседство со страданием и смертью, связанное с отречением от ,земной скверны ради небесной чистоты"4. Отсюда происходит экзальтация несчастной любви, „отвергающей как брак, так и плотскую связь, ради любовного страдания и смерти, без которой немыслимо мистическое единение с возлюбленной”5. Философ Дени де Ружмон видит в куртуазном стиле любви не столько стремление к плотской любви, сколько к поиску препятствий на ее пути. По мнению ученого, истинная подоплека куртуазной любви заключается в тайном влечении к смерти 6 . В средневековых легендах о любви часто встречается мотив существования любви за порогом смерти:

Тема посмертного соединения, причем, не обязательно непосредственного, но чаще символического - крон двух деревьев, тянущихся друг к другу цветов, табличек с вырезанными на них именами любящих - постоянно встречается в литературе и фольклоре 7 .

Дени де Ружмон в книге Любовь и Западный мир (L'Amour et l'Occident, 1939) констатирует, что романтическая любовь всегда запретна (противоречит существующим нормам), а возникающие на пути влюбленных преграды оказываются непреодолимыми. Романтическая любовь немыслима в ситуации, где все дозволено, поэтому без преград любовь, как и роман, существовать не может: чередование редких встреч и вынужденных разлук героев ложится в основу любовного сюжета. Склонность влюбленных к созданию преград (в случае отсутствия преград внешнего характера) Дени де Ружмон называет стремлением к смерти, гарантирующей бессмертие любви ${ }^{8}$. Философ обращает внимание на фонологическое сходство французских (латинских) слов amour и mort:

Любовь и смерть, смертельная любовь. [...] У счастливой любви нет истории. Роман интересует только смертельная любовь — то есть любовь, которой грозит опасность, чувство, обреченное на смерть самой жизнью. Ни чувственное наслаждение, ни плодовитое спокойствие семейной жизни не волнуют чувства в литературной культуре Запада. [...] Страсть должна нести страдание. Это фундаментальный факт 9 .

Таким образом, неотъемлемыми элементами романтической любви становятся смерть и страдание, что, по Де Ружмону, является следствием

3 Там же, с. 120.

${ }^{4}$ Е. Мелетинский, Средневековый роман, Москва 1983, http://svr-lit.niv.ru/svr-lit/meletinskij-srednevekovyj-roman/index.htm [дата обращения: 25.05.2017].

5 Там же.

${ }^{6}$ D. de Rougemont, Miłość a świat kultury Zachodniej, nep. L. Eustachiewicz, Warszawa 1999, с. 32. Там, где нет указания фамилии, переведено автором статьи.

7 А. Михайлов, Средневековые легенды и западноевропейские литературы, Москва 2006, https://www.litmir. me/br/?b=211069 [дата обращения: 25.05.2017].

${ }^{8}$ D. de Rougemont, Miłość..., c. 34.

9 Там же, с. 9. 
конфликта между eros (натуральным влечением) и agape (христианской жертвенностью).

Прототип романтической любви, в основу которого легла любовная доктрина трубадуров, появляется в XVIII столетии в произведениях ЖанаЖака Руссо Юлия, или Новая Элоиза (Julie ou la Nouvelle Hélö̈se, 1761) и Иоганна Гете Страдания юного Bepmepa (Die Leiden des jungen Werthers, 1774). Обращает на себя внимание схожесть черт любовного чувства, представленного Руссо со стилем куртуазной любви: идеализация возлюбленной, связь эротической формы мышления с этическим содержанием, смерть как обязательное завершение любовного сюжета. Отношения Юлии д’Этанж и Сен-Прё можно охарактеризовать как стремление к абсолютному единству, „чистый союз душ”, который способен преодолеть смерть и разлуку влюбленных:

О, умрем, моя нежная подруга, умрем, любовь моего сердца! Для чего нам отныне наша постылая молодость, - ведь мы изведали все ее утехи. [...] Божественная Юлия! Какое блаженство — обладать твоим сердцем, пред этим бледнеют восторги самой пылкой любви. Нет, я скорблю не оттого, что не вкушаю их! О, нет! Откажи мне, если так надобно, в упоительных ласках, за которые я отдал бы тысячекратно свою жизнь, но только дай мне вновь насладиться всем тем, что возвышеннее их в тысячу крат. Дай мне вновь насладиться тем слиянием душ, которое ты предвещала и позволила мне вкусить ${ }^{10}$.

Разлука для влюбленных не становится окончанием любви, напротив, она еще больше усиливает чувства:

Да, да, Юлия моя, никогда вы не были так прекрасны, как в тот миг, когда отвергли меня, хотя сознавать это и говорить об этом для меня пытка. Увы! Я вновь вас обрел, теряя вас ${ }^{11}$.

В романе Руссо физическое сближение является не целью, а одним из шагов к „абсолютному единению”. Невозможность соединения влюбленных, возникающие на их пути преграды, смерть одного из героев представлено как окончание любовной истории, но не окончание чувств. Роман заканчивается торжеством романтической любви. Перед смертью Юлия, выбравшая долг перед родителями и мужем, пишет своему бывшему любовнику: „Я ценою жизни покупаю право любить тебя любовью вечной, в которой нет греха, и право сказать в последний раз: «Люблю тебя»" 12 .

Те же самые черты обнаруживаются и в Страданиях юного Вертера Гете. Лотта для Вертера — „святая”, он обращается к ней: „Ах, Лотта, все, все напоминает здесь о тебе! Ты повсюду вокруг меня! Я, как ненасытное

10 Ж.-Ж. Руссо, Юлия, или Новая Элоиза, пер. Н. Немчиновой, А. Худаковой, Москва 1969, https://www.e-reading.club/bookreader.php/1023373/Russo_-_Yuliya\%2C_ili_Novaya_ Eloiza.html [дата обращения: 25.05.2017].

11 Там же.

12 Там же. 
дитя, собирал все мелочи, которых касалась ты, моя святыня!"13. В основу повествования также ложатся любовные переживания Вертера, чувство представлено как самая важная экзистенциальная проблема, повествование заканчивается самоубийством главного героя. Все это полностью отвечает романтическому индивидуализму и любовному стилю, который в XIX веке Стендаль в трактате $O$ любви (De l'amour, 1822) определит как l'amour passion. Любовь-страсть парадоксальна: она взаимна, но в то же время всегда несчастна. По словам Стендаля, ее несчастье заключается в отчаянии и смерти ${ }^{14}$. Позже l'amour passion объединит любовный дискурс произведений Руссо и Гете и получит название ,романтическая любовь”.

Мотив взаимной, но несчастной любви будет впоследствии встречаться у всех без исключения немецких романтиков ${ }^{15}$. Неотъемлемыми чертами романтической любви навсегда останутся конфликт страсти с общественными и социальными нормами, интриги и заговоры, препятствующие соединению влюбленных, отсутствие даже кратковременной стабилизации в отношениях героев, которая могла бы превратить отношения в рутину. Романтическая любовная история непременно завершается расставанием без надежды на новую встречу или смертью одного или обоих возлюбленных, после которой наступает воссоединение на небесах душ, не постигших счастья в жизни ${ }^{16}$.

В польской литературе, по свидетельству литературоведа Марии Янион, трудно найти произведения о романтической любви, соответствующие ее классическому канону. Достигнув своего наивысшего выражение в IV части Дзядов (Dziady część IV, 1823), тема эта, по словам ученой, так и не нашла своего певца ${ }^{17}$. Кроме того, и в произведении Мицкевича любовная тема осталась в тени из-за двойного самоубийства Густава и превращения „любовника женщины” в ,любовника Родины”.

В этом смысле особенное место в польской литературе занимает Хроника любовных происшествий (Kronika wypadków miłosnych, 1974) Тадеуша Кон-

${ }^{13}$ И. В. Гете, Страдания юного Вертера, пер. Н. Касаткиной, Санкт-Петербург 2007, https://books.google.pl/books?id=LjvGDAEACAAJ\&printsec $=$ frontcover\&hl=pl\&source=gbs ge_summary_r\&cad $=0 \# \mathrm{v}=$ onepage $\& \mathrm{q} \& \mathrm{f}=$ false [дата обращения: 20.06.2017].

14 Стендаль, О любви, [в:] он же, Собрание сочинений в 12 томах, т. 7, пер. М. Левберга, П. Губера, Москва 1978, http://az.lib.ru/s/stendalx/text_0040.shtml [дата обращения: 10.11.2017].

15 D. de Rougemont, Miłość..., c. 168.

${ }^{16}$ P. Boski, Kulturowe ramy zachowań społecznych, Warszawa 2010, c. 446.

17 Среди литературных борцов за право человека на интимную жизнь и ее превосходство над коллективным долгом Мария Янион называет также Бялошевского, назвавшего IV часть Дзядов своим любимым произведением; Пшыбышевского, „провоцирующего читателя неряшливым алкоголизмом, эротизмом и сатанизмом”; Гомбровича, которого „больше интересует психология личности, чем психология масс" (М. Janion, Tam gdzie rojsty. Przypadek romantycznego mediumizmu, [в:] еe же, Projekt krytyki fantazmatycznej, Warszawa 1991, c. 166). 
вицкого благодаря обращению писателя к дискурсу романтической любви. Этот роман является своеобразной литературной провокацией, собственной интерпретацией IV части Дзядов ${ }^{18}$.

Сам Конвицкий признавался, что он является жертвой романтического канона, в чем его „уличает” статья Марии Янион Tam gdzie rojsty:

Да, тот текст очень меня тронул, потому что я вдруг увидел себя в великом шествии жертв романтизма. Увидел, как несознательно делаю определенные жесты, следую определенным нормам поведения, и даже то, как я думаю, не осознавая, что это все умещается в канонах, запретах и требованиях польского романтизма. [...] Я являюсь продуктом романтического воспитания ${ }^{19}$.

Мария Янион называет Конвицкого „неистовым певцом” романтической любви, которая в Хронике любовных происшествий представлена как ,азарт, упоение, наркотик", чудо, которое преображает мир. В повести, следуя романтическому канону, главный герой „все ставит на одну карту”, которой являются чувства к Алине. Влюбленные в повести „находятся в трансе трубадуров”, религия любви дает им ощущение абсолютного счастья, неповторимого, счастья ангелов, а если ведет на дно несчастья, то до конца, бесповоротно, уничтожая и разрушая на всю жизнь ${ }^{20}$.

Виктор Астафьев, русский современник Конвицкого, тоже отмечал влияние истории о романтической любви на создание своей повести Пастух и пастушка (1971). Писатель так говорит о рождении замысла книги:

Как-то ехал в командировку в Кизил и проспал свою остановку. Вышел сгоряча на разъезде, чтоб возвратиться. Так я оказался на заброшенном полустанке. Выяснил: до поезда в обратном направлении чуть меньше суток. В общем - попал!... С собой пачка сигарет и книжка аббата Прево «Манон Леско». Дел никаких. Сел читать. Книга меня потрясла. Прочитал и задумался. А возможна ли сегодня — эта ситуация приключилась со мной впервые в послевоенные годы, — возможна ли в наши дни подобная романтическая любовь? Способны ли мы сейчас на такие чувства или хоть на похожую путаницу чувств?! Возник замысел вещи ${ }^{21}$.

Итак, импульсом к написанию повести Астафьева стала история любви дворянина кавалера де Грие и простой девушки Манон Леско, соответствующая канону романтической любви. Стендаль в трактате $O$ любви включил этот роман аббата Прево, наряду с Новой Элоизой Руссо, в список лучших книг о романтическом чувстве. Прежде всего, это любовь запретная, не одобряемая знатной семьей молодого влюбленного. На пути де Грие и Манон постоянно возникают препятствия внутреннего (измены ветреной Манон) и внешнего характера (заточение де Грие в доме отца, заключение

18 M. Janion, Tam gdzie rojsty..., c. 166.

19 Nasze histerie, nasze nadzieje. Spotkania z Tadeuszem Konwickim, ред. Р. Kaniecki, Warszawa 2013, c. 56-57.

${ }^{20}$ M. Janion, Tam gdzie rojsty..., c. 167-168.

${ }^{21}$ Цит. по: Ю. Ростовцев, Замысел, возникший на разъезде, [в:] его же, Виктор Астафьев, Москва 2014, с. 204. 
влюбленных в тюрьму). Радость встреч чередуется со страданием и отчаяньем во время разлуки, а хитросплетения судеб героев, тайные заговоры соперников и противодействие семьи де Грие не приносят даже кратковременной стабилизации совместной жизни героев. Заканчивается повесть трагической смертью Манон.

На первый взгляд, изысканный французский роман выглядит слишком отвлеченным от военных будней, изображаемых в повести Пасmyx u naстушка, и сопоставление двух произведений вряд ли было бы возможным без недвусмысленного авторского свидетельства. Поэтому мы будем говорить не о прямых соответствиях, а о образных перекличках и схожих мотивах. Можно отметить общую тональность произведений, в них преобладают ощущение тоски, грусти, щемящее чувство жалости, ощущение трагической развязки. Уже на первых страницах Пастуха и пастушки описания мертвой земли, „немой степи”, „погружают нас в стихию загадочного, трагического, романтического" 22 . На романтическое начало в главном герое повести указывал и сам писатель: „Что если он чувствовал чуть чувствительней, чем мы, грешные, что если романтическое начало в Борисе носило характер не внешний?"23. В повести Пастух и пастушка постоянно возникают отсылки к романтической эстетике. Эпиграфом к третьей части становится фрагмент из лирики вагантов:

Горькие слезы застлали мой взор,

Хмурое утро крадется, как вор, ночи вослед.

Проклято будь наступление дня!

Время уводит тебя и меня в серый рассвет ${ }^{24}$.

Вспомним, что поэзию вагантов открыли для нового времени романтики, чтившие безымянное творчество бродячих школяров, которое было для них „чем-то вроде народной латинской поэзии" 25.

Эпиграф к четвертой части Пастуха и пастушки взят из сонета Петрарки: „И жизни нет конца, и мукам — краю”. На фоне военной тематики эта цитата приобретает совершенно новое звучание, ассоциируясь прежде всего с ужасами войны. Но как мы помним, „виновницей” мук автора этих строк в сонете является Донна („И этому виной - о Донна, ты!”), пылкие чувства к которой возвели любовь итальянского поэта в ранг образцов европейского культа романтической любви.

22 Т. Тендитник, Новый эпос. Пастух и пастушка В. Астафьева, „Сибирь” 1985, № 3, c. 115 .

${ }^{23}$ В. Астафьев, Про то, о чем не пишут в книгах, „Литературная газета” 1979, № 40, c. 6 .

24 В. Астафьев, Пастух и пастушка, [в:] его же, Плач по несбывшейся любви, Пенза 1999, с. 104. В дальнейшем цитирую по этому изданию с указанием инициалов произведения и номера страницы в скобках.

25 М. Гаспаров, Поэзия вагантов, Москва 1975, с. 421. 
Включение романтического кода в произведения Конвицкого и Астафьева происходит в рамках двух разных концепций. В Хронике любовных происшествий актуализуется глобальная модель постструктурализма, в соответствии с которой „каждый текст является частью универсального текста и обусловлен им" 26 , даже если соотнесения с предшествующими текстами не осознаются самим автором. В Пастухе и пастушке реализуется герменевтическая модель, при которой происходит „сознательная, намеренная и засвидетельствованная отсылка" 27 к текстам или группе текстов. Вне зависимости от способа включения романтического любовного дискурса, важным для нас является обращение Конвицкого и Астафьева к романтической традиции в 70-е годы XX века и постоянно сопутствующий любовному сюжету мотив смерти в произведениях обоих писателей.

Любовный сюжет в Пастухе и пастушке развивается на фоне военных событий, героев Астафьева окружает смерть, которая на войне становится обыденным явлением. Борис и Люся ни на минуту не забывают о времени, в которое живут, они часто говорят о смерти. Если в повести Астафьева постоянное присутствие мотива смерти можно объяснить тем, что действие происходит на войне, то в романе Конвицкого - предощущением войны, действие романа развивается весной 1939 года. К концу романа сгущаются эпитеты, указывающие на приближение смерти: в долине течет „сісhа, martwa Wilenka”, в окно светит „księżyc, prostokąt martwego, przerażającego, światła”, „krwawo zachodzi słońce”, светит „niedobre, rude światło”.

Повествование в Хронике любовных происшествий наполнено ожиданием войны, ее неминуемым приближением. Действие в повести показано на фоне военных подготовок: „za urwiskiem w kanionie przedmieścia ciągle jeszcze śpiewali maszerujący żołnierze" 28 , ,żołnierze plotkowali na jaszczach z amunicją" [ХЛП, c. 203], ,na drodze ciągłe jeszcze przeklinali żołnierze, formując na nowo kolumnę dywizjonu" [ХЛП, с. 207], „, stronę dworca towarowego szły oddziały żołnierzy w rynsztunku bojowym" [ХЛП, с. 33]. Неизбежность катастрофы заставляет нас взглянуть на воссоздаваемый во всех мелочах довоенный мир как на символическое прощание с ним ${ }^{29}$. Стремительно развивающийся пасторальный романс контрастирует с историческим фоном, разговорами жителей Колонии Виленской о смерти и войне: „Mówią, że wojna będzie” [ХЛП, c. 30]; им являются знаки, предсказывающие будущее, мучают предчувствия надвигающейся катастрофы. Матери Витека снится „ogromny ogień. Wszystko się paliło, cały dom, całe miasto, cały świat” [ХЛП, с. 187]. Витеку является видение: „,dolina jest przywalona ruinami. Zamiast tych domów drewnianych

${ }^{26}$ R. Nycz, Intertekstualność i jej zakresy; teksty, gatunki; światy, [в:] Między tekstami, pед. J. Ziomek, J. Sławiński, W. Bolecki, Warszawa 1992, c. 35.

27 Там же.

28 T. Konwicki, Kronika wypadków miłosnych, Warszawa 2006, c. 200. В дальнейшем цитирую по этому изданию с указанием инициалов произведения и номера страницы в скобках.

${ }^{29}$ K. Demidowicz, Kronika wypadków miłosnych, „Film” 2001, № 8, c. 117. 
i murowanych widzi zarysy skruszonych fundamentów, widzi hałdy popiołu, widzi czarne belki i walące się ściany" [ХЛП, c. 169]. Идет красный дождь, сулящий „nieszczęścia i kataklizmy”, молния освещает „strasznym trupim światłem wszechświat Witka”.

Сопутствующий любовному сюжету мотив смерти перерастает в самостоятельную тему, представленную в аспекте натуралистическом (описания мертвецов в Хронике любовных происшествий, изображение искалеченных солдат в Пастухе и пастушке) и патетическом (масштабные картины сражений в современной пасторали Астафьева, упоение героев смертью в романе Конвицкого). Стоит также вспомнить о мотиве самоубийства: отец Витека повесился в лесу, новости из бульварной хроники сообщают о покончивших с собой из-за несчастной любви, Витек с Алиной решаются отравиться. Как и в книге Роланда Барта Фрагменты любовного дискурса (Fragments d'un discours amoureux, 1977), самоубийство в произведениях Конвицкого и Астафьева можно выделить в отдельную фигуру, которая часто возникает „в поле любовной страсти”

Безусловно, перечень фрагментов романтического любовного дискурса в Хронике любовных происшествий и Пастухе и пастушке будет неполным без фигуры смерти. По словам Марии Янион, романтическая любовь немыслимы без смерти, она является „любовью смерти”, и даже самой смертью ${ }^{31}$. Однако смерть в обоих произведениях не означает окончания чувств героев, напротив, смерть становится единственным приютом для влюбленных. В этом плане символичным представляется образ старика и старухи в повести Астафьева, убитых во время артобстрела:

Они лежали, прикрывая друг друга. Старуха спрятала лицо под мышку старику. И мертвых их било осколками, посекло одежонку, выдрало серую вату из латаных телогреек, в которые они оба были одеты. [...] Угрюмо смотрели военные на старика и старуху, наверное, живших по-всякому, [...] но обнявшихся преданно в смертный час [ПиП, с. 28].

Солдаты перед погребением стариков „попробовали разнять руки пастуха и пастушки, да не могли и решили так тому и быть..." [ПиП, с. 29]. Смерть пожилых супругов в художественной системе произведения возводится в ранг символа любви, которая после смерти обретает вечность. В подтверждение этому повесть Астафьева завершается обращением одинокой женщины к погибшему на войне возлюбленному: „Спи! Я пойду. Но я вернусь к тебе. Скоро. Совсем скоро мы будем вместе... Там уж никто не в силах разлучить нас" [ПиП, с. 162]. Эти слова перекликаются со строками поэта-романтика Генриха Гейне („Я сойду в могилу, чтобы к тебе

30 Р. Барт, Фрагменты речи влюбленного, пер. В. Лапицкий, Москва 1999, с. 329.

${ }^{31}$ M. Janion, Fragmenty dyskursu miłosnego, [в:] ee же, Kobiety i duch inności, Warszawa 2006, c. 146. 
прижаться”32), в которых слышится надежда на „фантазматическое соединение в смерти" 33 влюбленных.

Смерть становится единственным способом сохранить любовь и для героев Хроники любовных происшествий. Накануне своей последней встречи Алина и Витек говорят друг другу:

— Do ostatniej naszej chwili.

— Do początku nieskończoności [ХЛП, c. 216].

Смерть в произведениях Конвицкого и Астафьева преодолевает время и силы истории, обнаруживает мистическую надежду писателей на вечную любовь. Однако авторы создают лишь видимость реализации романтической модели любви, предполагающей смерть влюбленных. Оба писателя отходят от романтического канона: герои Конвицкого благополучно просыпаются после неудачного отравления, а Люся продолжает жить после смерти Бориса („А я вот живу. Ем хлеб, веселюсь по праздникам” [ПиП, с. 161]). Возвращение к жизни Алины и Витека оборачивается смертью их любви, об этом главному герою сообщает таинственный незнакомец, предсказывающий его будущее:

Zakradłbyś się do dziewczyny, którą, jak ci się wydaje, kochasz. Czy to ta z długim, czarnym warkoczem, Renia nia albco Musia, co zginęła później od bomby? Nie, zaraz, chyba nie zginęła, tylko przez Litwę wyjechała do Szwecji i wszelki słuch o niej zaginął [ХЛП, c. 153].

Прощаясь с Борисом, Люся забывает спросить его адрес, окончание любви героев неизбежно из-за отсутствия надежды на следующую встречу, ведь каждая „настоящая” любовь должна закончиться трагично.

Война и приближение войны в произведениях Астафьева и Конвицкого являются не только фоном, на котором представлена романтическая любовь, но и обязательным условием ее существования. Ведь без угрозы смерти и трагического расставания романтическая любовь существовать не может, любовный опыт романтического героя предполагает равное количество наслаждения и страдания. Романтическая любовь всегда на пороге расставания, она не ведет к полному удовлетворению и стабильности чувств. Она открывает перед героем новую экзистенциальную перспективу, погружает в ощущение постоянного беспокойства, а короткие мгновения счастья словно даны героям для того, чтобы острее почувствовать бездну отчаяния ${ }^{34}$.

Астафьеву и Конвицкому война представляется последним непреодолимым препятствием на пути соединения влюбленных в современном мире, что обусловливает выбор хронотопа в произведениях писателей. Ни пожи-

32 Цит. по: Р. Барт, Фрагменты..., с. 330.

33 Там же.

34 A. Fabianowski, Konwicki, Odojewski i romantycy. Projekt interpretacji intertekstualnych, Kraków 1999, c. 145. 
лому Витольду в Хронике любовных происшествий, ни „седой женщине с отцветающими древними глазами” в Пастухе и пастушке, в которой угадывается Люся, не довелось пережить подобные чувства в современном им мире. Поколение, к которому принадлежат герои, по мнению Конвицкого и Астафьева, - последнее поколение, способное пережить романтическую любовь.

Поэтому в 70-е годы XX века Конвицкий ищет своего героя в довоенном прошлом, считая, что его современникам недоступна романтическая любовь, они не способны ,zakochać się nieszczęśliwie i umrzeć potem z miłości” [ХЛП, с. 24]. В Хронике любовных происшествий писатель словно предсказал свое будущее разочарование в современнике. Вышедший в 1989 году фильм Лава (Конвицкий был сценаристом и постановщиком), представляющий собой взгляд на историческое зло сквозь призму Дзядов Мицкевича, не имел успеха. Зритель в 1989 году уже не стремился увидеть себя в зеркале шедевров национальной литературы, познать себя через искусство. Прокатный провал фильма Лава Мария Янион назвала завершением романтическо-символической формации, концом периода, в котором общественные поступки регулировались литературой ${ }^{35}$.

По мнению Конвицкого и Астафьева, переживание романтической любви недоступно в современном им мире, она была возможна в мире, который уже не существует. Отсюда грусть об исчезнувшем мире, о „старых годах” у Астафьева и рефреном звучащая у Конвицкого фраза „w tamtych czasach", похожая на аккорд, задающий тон каждой части повествования. Слышится тоска не только о настоящем чувстве, чуждом современникам, но и о ,человеке чувства”. И у Витека, и у Бориса, обнаруживается особая романтическая чувствительность и восприимчивость мира. Герою Астафьева снятся вещие сны, предвещающие его скорую гибель, у него обостренное чувство справедливости (он защищает Люсю от домогательств Мохнакова). Медсестра Арина жалеет умирающего Бориса: „Злосчастный ты, видать, уродился. Все люди как люди, а тебя что-то гнетет" [ПиП, с. 155]. Витек в Хронике любовных происшествий общается с духом, прибегает к заклятиям, гаданиям, ему является видение надвигающейся военной катастрофы.

Представляя общенациональную драму, Конвицкий воспевает драму сугубо личную. Он возносит интимные переживания в ранг наивысших ценностей, не ставя их ниже общенациональных идей. По Конвицкому, величайшим событием в биографии героев было ощущение неповторимости и уникальности их любви, возвышенности чувств, очарования миром. Поэтому, воскрешая в памяти прошлое, взрослый Витольд возвращается не к эпохальным событиям истории, а к воспоминанию о самом личном юношеском чувстве. Уберегая героя от смерти в молодости, Конвицкий лишь убеждает нас в том, что именно пережитая романтическая любовь была пиком его жизни. Хронику любовных происшествий вслед за Марией

35 P. Czapliński, Tadeusz Konwicki, Poznań 1994, c. 169. 
Янион можно назвать абсолютизацией любви „возвращением утраченного звена польского романтизма" 36 . Заголовки газетных хроник, сообщающие в повести о любовных драмах („Potwornej zbrodni studenta”, „Zamachach samobójczych”, „Kradta, aby uzbierać posag”, „Krwawy dramat miłosny”), свидетельствуют о вечности мелодрамы, в которой неразрывно существование любви и смерти, эроса и танатоса.

В отличие от Витека, герой Астафьева умирает молодым; его смерть от легкого ранения вызвала большой резонанс в критике, надежды читателя на встречу Бориса и Люси были обмануты. Можно предположить, что литературный ход Астафьева тоже является утверждением того, что героя в будущем не ждет ничего лучше, чем пережитое им чувство. Наше предположение подтверждают судьбы других астафьевских солдат в повестях Так хочется жить (1995) и Весельй солдат (1998), для которых из-за тягот послевоенной жизни тот свет кажется „приветливее”, чем этот, „давно проклятый и всеми ветрами продутый”. В послевоенной тематике произведений Астафьева мы не найдем романтическую пылкую любовь, любовь-озарение, любовь-,солнечный удар" - война истощила душу героев. Вместо романтической любви писатель будет изображать семейную любовь-жалость, отягощенную бытом.

Любовь в произведениях Пастух и пастушка и Хроника любовных происшествий можно определить как высший дар, кульминацию человеческой жизни. Трагические развязки любовных сюжетов (разлука влюбленных без надежды на встречу в Хронике любовных происшествий и смерть возлюбленного в Пастухе и пастушке) усиливают ощущение исключительности и неповторимости чувств героев. Романтическая любовь - это всегда любовь утраченная или обреченная на смерть, на расставание. Обращение Конвицкого и Астафьева к романтической модели любви в 70-е годы XX века свидетельствует, с одной стороны, об универсальности и устойчивости в литературе романтического любовного дискурса. С другой стороны, в этом угадываются грустные размышления писателей о невозможности любви, идеальной, поэтической, возвышенной, в современном мире. Это позволяет говорить не только мотиве смерти, но и о мотиве смерти любви в современной литературе.

\section{Библиография}

Астафьев В., Пастух и пастушка, [в:] его же, Плач по несбывшейся любви, Пенза 1999. Астафьев В., Про то, о чем не пишут в книгах, „Литературная газета” 1979, № 40. Барт Р., Фрагменты речи влюбленного, пер. В. Лапицкий, Москва 1999. Гаспаров М., Поэзия вагантов, Москва 1975.

Гете И. В., Страдания юного Вертера, пер. Н. Касаткинн, Санкт-Петербург 2007.

Мелетинский Е., Средневековый роман, Москва 1983, http://svr-lit.niv.ru/svr-lit/meletinskijsrednevekovyj-roman/index.htm.

36 M. Janion, Tam gdzie rojsty..., c. 169.

Slavica Wratislaviensia 167, 2018

(C) for this edition by CNS 
Михайлов А., Средневековые легенды и западноевропейские литературы, Москва 2006.

Ростовцев Ю., Замысел, возникший на разъезде, [в:] его же, Виктор Астафьев, Москва 2014. Руссо Ж.-Ж., Юлия, или Новая Элоиза, пер. Н. Немчинова, А. Худакова, Москва 1969.

Стендаль, О любви, [в:] он же, Собрание сочинений в 12 томах, т. 7, пер. М. Левберга,

П. Губера, Москва 1978, http://az.lib.ru/s/stendalx/text_0040.shtml.

Тендитник Т., Новый эпос. Пастух и пастушка В. Астафьева, „Сибирь” 1985, № 3.

Хейзинга Й., Осень Средневековья, пер. Д. Сильвестров, Москва 1995.

Boski P., Kulturowe ramy zachowań społecznych, Warszawa 2010.

Czapliński P., Tadeusz Konwicki, Poznań 1994.

Demidowicz K., Kronika wypadków miłosnych, „Film” 2001, № 8.

Fabianowski A., Konwicki, Odojewski i romantycy. Projekt interpretacji intertekstualnych, Kraków 1999.

Janion M., Fragmenty dyskursu miłosnego, [в:] еe же, Kobiety i duch inności, Warszawa 2006.

Janion M., Goraczka romantyczna, Gdańsk 2007.

Janion M., Romatyzm i jego media, [в:] ee же, Prace wybrane, т. 4, Kraków 2001.

Janion M., Tam gdzie rojsty. Przypadek romantycznego mediumizmu, [в:] еe же, Projekt krytyki fantazmatycznej, Warszawa 1991.

Konwicki T., Kronika wypadków miłosnych, Warszawa 2006.

Nasze histerie, nasze nadzieje. Spotkania z Tadeuszem Konwickim, ред. P. Kaniecki, Warszawa 2013.

Nycz R., Intertekstualność i jej zakresy; teksty, gatunki; światy, [в:] Między tekstami, ред. J. Ziomek, J. Sławińskiego, W. Boleckiego, Warszawa 1992.

Pearce L., Romance Writing, Cambridge 2007.

Rougemont D. de, Miłość a świat kultury Zachodniej, пер. L. Eustachiewicz, Warszawa 1999.

\section{The motive of death in romantic discourse of love in modern Polish and Russian literature (in the novels $A$ Chronicle of Amorous Accidents by Tadeusz Konvitski and $A$ Shepherd and a Shepherdess by Viktor Astafiev)}

Summary

The motive of death belongs to the most essential motifs in romantic discourse of love. Death-wish is the force that drives and explains the literary and cultural history of romantic love from the Middle Ages to the present.

The first part of the article brings together historical, religious, philosophical, and cultural appearance of romantic love and its connection with the motive of death. The second part of the work presents the analyses of that motive in romantic discourse of love in modern Polish and Russian literature.

With the use of fragments established by Roland Bart in A Lover's Discourse: Fragments, the author demonstrates the necessity of distinguishing the death as a fragment of romantic discourse of love. In A Chronicle of Amorous Accidents and A Shepherd and a Shepherdess a motive of death is connected with love stories, and becomes a metaphor of the triumph of love over death.

Keywords: Viktor Astafiev, Tadeusz Konwitski, discourse of romantic love, love and death, motive of death 


\section{Motyw śmierci w dyskursie miłości romantycznej współczesnej literatury polskiej i rosyjskiej (na materiale powieści Pasterz i pasterka Wiktora Astafjewa i Kronika wypadków miłosnych Tadeusza Konwickiego)}

\section{Streszczenie}

Motyw śmierci można uznać za jeden z najbardziej istotnych motywów romantycznego dyskursu miłosnego. Żądza śmierci jest siłą, która napędza i wyjaśnia literacką i kulturową historię romantycznej miłości od średniowiecza do współczesności.

Pierwsza część artykułu łączy historyczne, religijne, filozoficzne i kulturowe warunki pojawienia się romantycznej miłości i jej związek z motywem śmierci. Druga część artykułu poświęcona jest analizie tego motywu w dyskursie miłości romantycznej we współczesnej literaturze polskiej i rosyjskiej. Posiłkując się ustaleniami Rolanda Barthes’a z książki Fragmenty dyskursu miłosnego, autorka dowodzi, że śmierć można uznać za fragment romantycznego dyskursu miłosnego. W Kronice wypadków miłosnych i Pasterze i pasterce motyw śmierci towarzyszy historiom miłosnym, staje się metaforą triumfu miłości nad śmiercią.

Słowa kluczowe: Tadeusz Konwicki, Wiktor Astafjew, dyskurs miłości romantycznej, motyw śmierci 